Review

\title{
Co-Creating a "Sustainable New Normal" for Social Work and Beyond: Embracing an Ecosocial Worldview
}

\author{
Meredith Powers ${ }^{1}$, Michaela Rinkel ${ }^{2}$ and Praveen Kumar ${ }^{3, *(D)}$ \\ 1 Department of Social Work, University of North Carolina Greensboro, Greensboro, NC 27412, USA; \\ mcfpowers@uncg.edu \\ 2 Department of Social Work, St. Mary's University of Minnesota, Minneapolis, MN 55404, USA; \\ mrinkel@smumn.edu \\ 3 School of Social Work, Boston College, Chestnut Hill, MA 02467, USA \\ * Correspondence: praveen.kumar@bc.edu
}

check for

updates

Citation: Powers, M.; Rinkel, M.; Kumar, P. Co-Creating a "Sustainable New Normal" for Social Work and Beyond: Embracing an Ecosocial Worldview. Sustainability 2021, 13 10941. https://doi.org/10.3390/ su131910941

\section{Academic Editors:}

Komalsingh Rambaree,

Sandra Engstrom and Jennifer Boddy

Received: 27 July 2021

Accepted: 22 September 2021

Published: 1 October 2021

Publisher's Note: MDPI stays neutral with regard to jurisdictional claims in published maps and institutional affiliations.

Copyright: (c) 2021 by the authors. Licensee MDPI, Basel, Switzerland. This article is an open access article distributed under the terms and conditions of the Creative Commons Attribution (CC BY) license (https:// creativecommons.org/licenses/by/ $4.0 /)$.

\begin{abstract}
We have an opportunity to help shape new systems and structures that redress injustices and course correct us for a trajectory that is infinitely better than the one on which we are now set. We can co-create a sustainable new normal, intentionally and mindfully, alongside those who are most impacted by factors of oppression, exacerbated by the COVID-19 pandemic. Such a new trajectory would mitigate both the unintentional harm and blatant atrocities done to people and our ecosystem, as well as heal and promote holistic, mutual well-being. Since the dawn of the profession, many social workers have practiced using an expanded understanding of the person-environment framework (i.e., social, political, economic, and environmental) and have drawn upon Indigenous worldviews. However, our current mainstream professional models are entrenched in the growth ideology, which perpetuates the very injustices that we seek to eliminate. Therefore, we need to embrace an ecosocial worldview, shifting conversations and actions towards alternative approaches and establish new policies and practices. In order to equip the profession to meet these roles and responsibilities and address these interwoven injustices, we highlight examples of real, successful alternatives implemented across the globe and pose considerations for re-envisioning and co-creating a sustainable new normal, for the profession and beyond.
\end{abstract}

Keywords: ecosocial worldview; sustainability; sustainable development; sustainable new normal; degrowth

\section{Envisioning a "Sustainable New Normal"}

With the world in disarray and heartache, we offer an alternative, realistic vision of a "sustainable new normal". This new normal is one that many social workers are already co-envisioning and co-creating, intentionally and mindfully, alongside those who are most impacted by factors of oppression, exacerbated by the COVID-19 pandemic [1,2]. In today's current context, we have an opportunity to help shape new systems and structures that redress injustices and course correct us for a trajectory that is infinitely better than the one on which we are now set. Such a new trajectory would be one that not only mitigates both the unintentional harm and blatant atrocities done to people and our ecosystem (i.e., "Web of Life") but is also one that heals and promotes mutual flourishing. In this sustainable new normal, the mainstream of our profession, along with the world at large, would firstly recognize that it currently operates within an anthropocentric or human-centric worldview. In this worldview, humans are considered above or outside of the ecosystem in which they exist. This perpetuates structures and practices of injustice, extraction, and destruction. Once the mainstream recognizes these limitations, we can then strive to embrace an ecosocial perspective which acknowledges humans as one species within an interrelated Web of Life, thus promoting a holistic well-being [3]. Operating from an ecosocial worldview, many social workers are already engaging as visionaries and 
innovators in alternative approaches that co-create such a new normal [4,5]. In dreaming of and co-creating our sustainable new normal, let us consider Sonya Renee Taylor's poignant challenge:

"We will not go back to normal. Normal never was. Our pre-corona existence was not normal other than we normalized greed, inequity, exhaustion, depletion, extraction, disconnection, confusion, rage, hoarding, hate and lack. We should not long to return, my friends. We are being given the opportunity to stitch a new garment. One that fits all of humanity and nature" [6].

\section{Research Gap}

Relentless economic growth is considered a gold standard to measure societal wellbeing, in which activities that spur economic growth remain a central focus of development. There is an overwhelming notion that "more money brings more well-being". This notion is plagued with pernicious environmental consequences, increased inequalities, and unsustainable social structures. The implications of a human-centric worldview are so pervasive that alternative worldviews are highly understudied from an academic perspective. Thus, systematic attention on the ecosocial worldview, as a sustainable alternative, is needed more so than ever.

It is beyond the scope of this manuscript to critique all the problems of an anthropocentric worldview, as they are too numerous and complex. However, we intend this manuscript to serve as a rallying cry to stop our current trajectory based on anthropocentrism and consider real, alternative possibilities that have successfully been implemented across the globe. We should no longer indulge in mindlessly serving the socioeconomic ideology (i.e., growth ideology) which equates growth exclusively with prosperity and overvalues profit, no matter the costs. We should not passively accept the mainstream ways of doing things that stem from a human-centric worldview. We should not be hopelessly destined to endure and merely respond to the ongoing onslaught of suffering in the world. By shifting to embrace an ecosocial worldview, we can re-examine the structures and systems in which social work exists as a profession and continue to co-create a sustainable new-normal for our profession and beyond. In order to do this, we must first examine some of the flawed human-centric worldview and ideologies which have enveloped the structures and systems in which our profession has come into being and is currently situated.

\section{2. "How's the Water?"}

There is a parable that says: There are two young fish swimming along one day and they come upon an older fish, swimming the other way, who nods at them and says, "Good morning. How's the water?" The two young fish nod politely back and swim on for a bit. Eventually, one of them looks over at the other and says, "What is 'water'?"

Like the fish in this parable, we operate daily, living and breathing and rarely, if ever, questioning the worldview and ideologies in which we are immersed. A worldview is how one sees one's relationship to the world, and often remains unconscious and unexamined. Ideology is a system of beliefs or ideas that arises from one's worldview, often used in the context of developing political and economic theory. Ideologies are not set in stone, rather, they can and should be re-evaluated as one's worldview shifts.

\section{Growth Ideology: Why We Face Injustices and a Global Climate Crisis}

One prevalent ideology embraced in many parts of the world is the "growth ideology". Situated in a human-centric worldview, growth ideology promotes economic gain through development as if it is essential to human well-being. However, it has been proven that the opposite is true [5,7]. The growth ideology emphasizes the continual increase in the production of goods and services, despite the costs to people and planet. Within a growth ideology, the entire economic system is actually based on "affluence" and not "prosperity". 
The growth ideology, solidified during the industrial revolution, has been mainstreamed throughout much of the world and is typically coupled with neoliberalism. Neo-liberalism promotes free market capitalism in all aspects of society such as growth for development, despite the array of unsustainable consequences, undercutting environmental and social protection systems, and exacerbating oppression and atrocities [8]. Development within the growth ideology was, and continues to be, the primary source of the problems that we in social work fight so diligently to alleviate (e.g., economic, political prosperity for a few at the expense of others and the environment) [7]. There is an increased recognition that we are in a global climate crisis, and we must address unsustainable societies and the related injustices through collective action for sustainability [9].

In the 1970s, "sustainable development" as opposed to "development", was heralded throughout the world as the solution to the increasing recognition of global limits and the interrelated injustices, both to humans and the planet. However, stemming from a human-centric worldview and situated in the growth ideology, sustainable development and the global framework of the United Nations' Sustainable Development Goals (SDGs) are problematic on many fronts, which we will critique in greater detail below. Let us first take a moment to examine the concept of "sustainability" and the ways it has been misconceived and misconstrued.

\section{Sustainability: Misconceptions and Mixed Messages}

Sustainability has become a buzz word in popular discourse, especially around environmental sustainability. Sustainability indicates that a system has the ability to be maintained and renewed within a normal balance of lifecycles, not becoming depleted or extinct. Defining sustainability as merely about the natural environment is incomplete as it ignores the social systems that intertwine with the environment. These social systems are the elements that determine whether the broad ecological system is sustainable. Social systems include worldviews, culture, economics, politics, family, and community subsystems, each contributing to overall sustainability. So, efforts to move toward sustainability necessitate consideration of how to create healthy and just political, economic, family, and community systems that also support the natural environment. This is the social aspect of sustainability. The ability of the ecosystem to be maintained and renewed within normal balance of lifecycles has been and continues to be an essential element of cultures using an ecosocial worldview. For example, one concept of "seventh generation thinking" compels us to make decisions about how we live now with full consideration of how it will impact the well-being of the entire ecosystem or Web of Life at a future point in time, seven generations from now.

\subsection{The "Sustainable Development" Conundrum}

Sustainable development and sustainability have become wedded in popular discourse so much so that they are frequently used interchangeably. However, sustainability does not mean sustainable development. As noted above, sustainable development was originally put forth as a solution to the development model to address the growing concerns of the limits to growth and the apparent injustices that were prevalent in the growth ideology's development model. Sustainable development can be defined as development that meets the needs of the present without compromising the ability of future generations to meet their own needs $[10,11]$. It contains two key concepts: the concept of "needs", in particular, the essential needs of the world's poor, to which priority should be given, and the idea of limitations imposed by the state of technology and social organization on the environment's ability to meet present and future needs [12,13].

This concept of sustainable development introduces consideration for the future with two essential ideas: the priority of the needs of those who are oppressed, and the recognition of biophysical boundaries. While the first has been ignored within the mainstream, the second is already relativized in the definition itself as a matter of technological development $[13,14]$. The 1987 Brundtland report on sustainable development is a seminal 
discussion on this concept [14]. However, the report goes no further than qualifying the kind of growth that would be needed, instead of fundamentally rethinking "development" [15]. The report does not acknowledge the absolute limits in the natural environment; instead, it assumes that technology will overcome those limits. Another critical assumption that the Brundtland Report holds is that economic growth and increase in consumption paves the way for development. There is an emphasis on consumerism and excessive materials and resource use [16]. The measure of a growing economy, Gross Domestic Product (GDP), is a nation's topmost priority and dominates political institutions. This priority is seminal to the assumption that affluence correlates with well-being [17]. An increase in GDP could lead to higher income levels and is routinely considered symptomatic to greater prosperity. However, there is a problem with this developmental philosophy. GDP growth necessitates continuous cycles of production and consumption, demanding ever-increasing environmental resources, driving degradation and contributing to the global climate crisis.

Despite the admirable idea to include sustainability (which originates in an ecosocial worldview) within contemporary approaches of "GDP fueled" development (which is based on an anthropocentric worldview) to create "sustainable development", it ultimately just created another model that remains situated in the anthropocentric and neoliberal economic paradigm. Cycles of production and consumption undergird this growth ideology. Profit will always prevail over the aspirations of meeting the supposed competing needs of people and planet. Ultimately, this framework will only serve to further perpetuate ecological injustices and power imbalances $[7,18]$. Thus, sustainable development is a conundrum. It is impossible to keep developing within the existing paradigm of growth ideology and realize genuine sustainability. Below, we present further evidence of this conundrum as we discuss how sustainable development has been envisioned and implemented as the global framework of the SDGs.

\subsection{United Nations' Sustainable Development Goals: Evidence of Conundrum}

A response to the Brundtland Commission Report was the development of the (SDGs). These 17 SDGs are responsive to the most pressing challenges that the world is grappling with. Adopted in 2015, the SDGs have been lauded for their ability to create a common language to address complicated global issues and acknowledge the necessity of global cooperation in order to achieve well-being. The SDGs contain no mention of a need for a reduction in either consumption or production. The United Nations [19] writes that these goals are "an urgent call for action by all countries... [in order to] end poverty and other deprivations [that] must go hand-in-hand with strategies that improve health and education, reduce inequality, and spur economic growth." The last three words are exactly why these goals resist the realization of sustainability from an ecosocial worldview. The push for economic growth perpetuates production-consumption cycles. This indeed could lead to an increase in the GDP, but often exacerbates environmental degradation. Ultimately, the outcome of this framework, including its aims and measures of success, is still part of the growth ideology and thus can only take us so far in achieving some aspects of sustainability.

While the SDGs do move us beyond mere development to sustainable development, they still rely on the erroneous assumption that sustainability can be achieved through development which is based on "sustained, inclusive, and sustainable economic growth" (SDG 8). Goal 8 (Decent Work and Economic Growth) specifically calls for a 7\% growth rate target, measured by GDP [19]. This means the propagation of routine cycles of production and consumption on the basis of which GDP growth is sustained. Goal 7 (Affordable and Clean Energy), for example, focuses on efficiency and increasing sustainable energy practices. However, it does not mention the need for reduced energy consumption to help reduce throughput. From an ecosocial lens, achieving responsible forms of consumption or production is impossible without cuts in matter/energy throughput. In other words, Goal 7 is difficult to achieve if Goal 8 needs to be achieved. Furthermore, as currently, most economies rely on fossil fuels, a relentless push for at least a $7 \%$ increase in GDP 
could perpetuate fossil fuel use. Such reliance could inhibit transition to clean energy (Goal 7) and constrain the realization of Goal 13 on climate change. Critics have argued that supporting economic growth as conceptualized in the UN SDGs could lead to greater social inequality and cause a greater spread of unsustainable production and consumption across the globe [20]. Looking closely at Goal 9 ("build resilient infrastructure, promote inclusive and sustainable industrialization and foster innovation"), one can see that economic and technological growth is portrayed as central to sustainable development. However, reduction in economic activity to reach a safe operating space that is ecologically sustainable finds little traction in the SDGs [21].

The process to develop the SDGs represents a great accomplishment of collaboration and compromise. However, they have also been criticized, as we have briefly noted above, and though the SDGs have some strengths and benefits to humans and to the planet, they fall short of the bigger, longer-term purpose of realizing sustainability and true well-being for the Web of Life, including future generations. In light of this, alternative discourses and approaches have arisen which question an anthropocentric model of sustainable development [7,22-24]. They call for a paradigm shift to an ecosocial worldview, which leads to a truly sustainable path that does not keep perpetuating the unsustainable and unjust byproducts of growth, be they from mere development or "sustainable development" [7]. Social workers around the world have already been operating within the SDGs and beyond as they embrace an ecosocial lens. Let us now further explore this history, current roles, and our potential future as a profession.

\section{Social Work and Sustainability}

Social work's primary concern is well-being and has, at its core, attention to human equality and inclusion and the interactions of humans and their environment. The social work profession's unique perspectives and skill sets are needed as we address the climate crisis. These include our emphasis on social justice, empowerment, the strengths perspective, and the person in environment perspective, along with the approach of using a systems framework. These social work perspectives help to make more evident the power dynamics that exist and highlight the ways they are changed as we work to alleviate injustices related to poverty, inequality, and oppression, often connected to environmental and ecological injustices.

We celebrate the work of the profession to increase inclusion of the natural environment in our practice and research. Progress is evident in many of our professional organizations and priorities such as the Global Agenda for Social Work and Social Development, the Grand Challenges, the NASW Social Justice Priorities, the NASW statement on the environment, CSWE inclusion of environmental justice in the Education Policy and Accreditation Standards, creation of ecosocial work networks, and the creation of conference tracks on environmental social work in our education and research [5,7]. Social work practice is clearly connected to the SDGs. As partners with and leaders in many communities where the work related to the SDGs occurs, we are essential workers in the promotion of community and environmental sustainability in service to the achievement of the SDGs.

As one example, for over a decade now, the Global Agenda for Social Work and Social Development (2010-2020) (The Global Agenda) has included the promotion of community and environmental sustainability as one of its four pillars. This created a global professional mandate as researchers, practitioners, and educators to address environmental/climate justice issues. The Global Agenda mandates that we promote sustainable communities and environments. Around the world, social workers are coming alongside communities that are unfairly impacted by climate injustices to create solutions that are prioritized by the local communities. The Global Agenda continues to expand for the upcoming decade, with the first theme of "Ubuntu", an Indigenous principle interpreted as "I am because we are", calling attention to the inextricable interconnectedness of all life as we seek mutual well-being [25]. 
Social work has been a critical voice, calling for attention to the structures that further inequality in all systems. However, the profession gradually adapted a distorted ecological theory to inform primarily the social environment, to the exclusion of the natural environment [26]. Rather, attention was given to understanding the effects and influences related to the social environment (e.g., political, economic). Many in social work, possibly inadvertently, contributed to entrenchment of the view that well-being is synonymous only with social and economic growth. The COVID-19 crisis has further demonstrated how perilous a "growth ideology" (e.g., capitalism, neoliberalism) truly is. This prevailing ideology has accelerated injustices, exacerbated global health disparities, both within and between nations, through the mindless pursuit of wealth aggregation at any cost. Even in the attempts to address these disparities and destruction prior to and now considering crisis, points us to a need for different ways of doing things.

Some social workers have given voice to the need to uncouple that errantly assumed relationship of growth and well-being, including Indigenous scholars and practitioners, critical theorists and practitioners, and ecosocial social workers (as we define further below). However, these voices have been marginalized, limiting their impact on the transformation of the core of the profession that is critically necessary. Because of this, social work has settled into a space of mitigation, addressing the devastating effects of the growth model to people and the environment but not truly transforming the structures that create them. This is our current normal, as a profession. An ecosocial worldview calls us to question the growth ideology. A degrowth approach, which can lead to or come from an ecosocial worldview, is one vehicle to move towards the transformation necessary to address such challenges $[5,7]$.

\section{A Way Forward: Embracing an Ecosocial Worldview}

Much of the mainstream social work research and practice operates out of a framework that does not manifest the urgent transformations needed for a sustainable future. Our profession's predominant ways of being, knowing, and doing in the world are inadequate. The foremost economic model that equates well-being with economic growth is false and has actually been shown to accelerate injustices and trivialize holistic well-being [7]. The current global economic crisis sparked by the COVID-19 pandemic has further demonstrated this fact. The pandemic has highlighted the multiple, intersecting, and ongoing oppressions based on race, ethnicity, color, gender, sexual orientation, nationality, language, ability, religion, spirituality, etc. [27]. This is evidenced in the countless preventable deaths and tragedies. These interwoven injustices demand that we co-envision and cocreate, with local and global communities, a sustainable new normal for the profession and beyond [28,29].

We are using the term ecosocial work to describe this change in social work, but there are other terms being used that indicate this change in thinking including green social work [30], ecological social work [24], and environmental social work [29]. We have chosen ecosocial work because we believe it emphasizes the ecological nature of the systems in which we work and explicitly connects to the ecosocial worldview [3].

A concerning segregation appears to be happening that separates 'environmental social workers' from the majority of the profession, mislabeling the role and responsibility of including concern for natural and built, physical environments and their relationship to social well-being as a "specialty field of practice" or niche. In order to bring the substantial changes needed, ecosocial work needs to be seen as centered in all social work, not relegated to the margins or seen as a niche. This requires social workers' examination of their current worldview and embracing a worldview that centers the environment in our promotion of well-being.

Ecosocial work is not new. Specifically, this has been true of social work from Indigenous ways of knowing, being, and doing, prior to becoming a formalized profession of social work and continuing on with those who are embracing Indigenous knowledges and an ecosocial worldview $[26,29]$. However, these have been largely dismissed and ignored 
by mainstream social work. Additionally, we acknowledge that since the formalization of the mainstream profession, during the industrial revolution, some social workers have practiced and researched with attention to how the natural environment impacts clients and communities, but they primarily did so from an anthropocentric worldview. For example, these social work pioneers researched and developed programs in the environmental space such as garbage collection needs, parks and recreation/green spaces in cities, and harmful work environments [31]. However, as with the conundrum of sustainable development that can never truly be achieved within an anthropocentric worldview, the same conundrum is present within social work. Thus, social workers, who do not already hold to an ecosocial worldview, need to shift to embrace it in order to establish new policies and practices to move beyond the current professional models that are entrenched in perpetuating the very injustices that we seek to eliminate.

While many social workers practice within an expanded understanding of the personenvironment framework (i.e., social, political, economic, and environmental), some have additionally moved away from or rejected anthropocentric perspectives and have instead drawn upon Indigenous worldviews to forward what is now known as ecosocial work $[3,4,26,28,31]$. Ecosocial work is social work, with an expanded framework and worldview that considers how humans are a part of the ecosystem and seeks to achieve balanced justice for the entire ecosystem, not the predilection of humans at the expense of the planet $[5,28]$.

Holism is at the core of the ecosocial worldview and moves us beyond the distorted, narrow person-in-environment framework that has been such a defining aspect of our mainstream profession. Holism posits that every aspect of life is interconnected within a much larger system. This has significant implications for social work. The well-being of people is inextricable from the well-being of the planet. This moves our understanding of person-in-environment to person-as-environment or person-as-place, where the environment and person are seen as part of the same holistic entity, or a Web of Life [26]. The well-being of one element in the system impacts the well-being of all. Holism moves away from a worldview that separates humans from nature to a relational view, focused on collective well-being and our interdependence with all parts of the ecosystem. The principle of "ubuntu-I am because we are" echoes this by not limiting the "we" to humans, but inclusive of more than humans and the physical environment [25].

The ecosocial worldview directs us away from dualistic thinking such as health-mental health, well-being of the planet-well-being of humans, and spirit/mind-body. This tendency toward dualism around the environment and humans arose from our historical externalization of nature [32]. Dualistic thinking emphasizes differences and leads to privilege and oppression as it calls for distorting the genuine connections between self and others [32]. The domination of beliefs that separate humans from nature and celebrate individualism over collective good maintains a system of inequality and oppression. The injustices to the planet arise from the same forces that maintain oppression of people. This system suggests that competition and consumerism are the way to secure individual well-being.

The ecosocial perspective is reflected in many Indigenous worldviews that recognize the interdependent relationship between humans and the more than human world or Web of Life [3]. This reconceptualizes well-being. Well-being is more relational as we recognize ourselves as part of a complex system. A holistic perspective on well-being focuses on those relationships between elements in the system, including human and nonhuman living things. Well-being of the natural world is linked to individual well-being. Well-being of oneself is linked to the well-being of others, even across the globe. Again, "ubuntu" is an evident principle here. This suggests the need for a global perspective that emphasizes the global connections between peoples and places. The nature of our current environmental crisis serves as an example of the need for this global perspective of well-being. Industrialized countries are responsible for much of the degradation of the planet, but the impact is disproportionately experienced by the non-industrialized countries. Solutions need to keep this holistic perspective in mind. This shift in how we 
understand our well-being, a core emphasis of social work, necessitates the reexamination of how we use and distribute resources, demanding fairness and equity [5].

Ecosocial work targets the development and maintenance of ecosocially sustainable and inclusive communities as a primary aim of the profession $[7,31]$. In order to do this, the profession needs to focus on changing societal structures, many economic, to move us beyond the limitations of the growth based economic models. We also note that Indigenous knowledges and the ecosocial worldview have offered discourses and solutions in this or similar veins since the dawn of history and continues today. Some of the alternative economic concepts that emphasize social and ecological connectedness rather than competition and scarcity are the doughnut economy, degrowth or post-growth, diverse economy, solidarity economy, and community-based economy and commons [33]. We have identified the degrowth approach $[34,35]$ as offering concrete ways that social work can promote genuine and holistic well-being.

Practice from an ecosocial worldview requires the significant transformation of mainstream social work practices. For some, these elements are already embedded in and consistent with their deeply held beliefs and values. For others, the change is truly transformational as they seek to critically investigate and potentially unearth beliefs and values that have long been buried beneath generations of movement away from an ecosocial worldview, which acknowledges our interconnected roots. Table 1 summarizes the elements of social work practice that we have currently identified as key to practice from an ecosocial worldview We note these are not discrete categories, as they are inextricably intertwined; however, for purposes of helping those within an anthropocentric worldview, we offer this as a way to tease out some aspects in order to help them better understand and incorporate them when shifting to embrace an ecosocial worldview. We also note that the practice examples we provide in the table are elaborated upon in the sections below and are not discrete to only one element.

Table 1. Social work practice from an ecosocial worldview.

\begin{tabular}{|c|c|c|}
\hline Elements of Ecosocial Work & Definition & Implications for Social Work Practice \\
\hline Holism & $\begin{array}{l}\text { Every aspect of life is interconnected within } \\
\text { a larger system. }\end{array}$ & $\begin{array}{l}\text { - } \quad \text { Focus on recognition of people as part of nature } \\
\text { - } \quad \text { Value connections between all aspects of the Web of Life } \\
\text { Consideration of rights and justice for all within the } \\
\text { Web of Life } \\
\text { - A practice example is the use of circular economies }\end{array}$ \\
\hline Interdependence of Well-being & $\begin{array}{l}\text { Each aspect of the Web of Life is dependent } \\
\text { upon the well-being of all in the system, } \\
\text { shifting emphasis from individual } \\
\text { well-being to collective well-being. Progress } \\
\text { occurs through improving healthy living for } \\
\text { all parts of the Web of Life. }\end{array}$ & $\begin{array}{l}\text { Localize solutions that emphasize local knowledge, } \\
\text { cooperation, shared abundance, and reciprocity } \\
\text { Ensure opportunities for all in the Web of Life to be } \\
\text { healthy and thrive. } \\
\text { Enhance and foster quality relationships within the } \\
\text { Web of Life. } \\
\text { Practice examples include utilizing Indigenous/local } \\
\text { solutions and time banking }\end{array}$ \\
\hline $\begin{array}{l}\text { Systemic Connections and } \\
\text { Relationships }\end{array}$ & $\begin{array}{l}\text { Strong relationships within the Web of Life } \\
\text { promote holistic health. Focus is not on } \\
\text { simply meeting human needs but to ensure } \\
\text { thriving and abundance for all in the Web of } \\
\text { Life, including future generations. }\end{array}$ & $\begin{array}{l}\text { Diminish use of dualistic thinking that distorts and } \\
\text { diminishes connections } \\
\text { - } \quad \text { Strengthen relationships within the eco-system. } \\
\text { - } \quad \text { are connected, locally and globally, and need to } \\
\text { Practice examples include farmers markets and } \\
\text { time-banking }\end{array}$ \\
\hline $\begin{array}{l}\text { Ecosocially Sustainable and } \\
\text { Inclusive Communities }\end{array}$ & $\begin{array}{l}\text { Need to promote health of the Web of Life } \\
\text { and ensure that demands to meet human } \\
\text { needs does not upset the balance of the } \\
\text { system. This recognizes the limits to } \\
\text { economic growth and calls for decoupling of } \\
\text { economic growth as singularly essential to } \\
\text { well-being. Sustainability emphasizes } \\
\text { long-term thinking and consideration. }\end{array}$ & $\begin{array}{l}\text { Replace structures that emphasize competition and } \\
\text { scarcity with ones that emphasize social and ecological } \\
\text { interdependence and abundance } \\
\text { Practice examples, such as time banking Indigenous } \\
\text { solutions, and circular economies illustrate movement } \\
\text { toward sustainable communities }\end{array}$ \\
\hline
\end{tabular}




\section{Degrowth Approach: A Vehicle towards Embracing the Ecosocial Worldview}

We are not highlighting degrowth because it is a new way of thinking, but from our positionality, coming from anthropocentric cultures of origin and seeking to understand other worldviews, this resonated with us as we began shifting toward embracing an ecosocial worldview. We note that degrowth is not intrinsically a derivative of an ecosocial worldview but could be a vehicle that moves towards embracing one. The degrowth approach offers alternatives to the growth ideology. The central tenet of degrowth is to reduce economic activity (consumption and production) to reach a safe operating space or a level of economic activity that can be considered as truly, ecologically sustainable [17]. We must acknowledge that the natural environment sets absolute limits on human action and recognize the fundamental incompatibility between relentless economic growth and ecological conservation.

The degrowth approach recognizes that society requires a fundamental social transformation. We must start to advocate limits to growth and that infinite economic growth cannot occur on a finite planet. One of the characteristics that strengthens the degrowth approach is that it is not strictly limited to academic discussions and literature but is also a social movement. This means not only changing the ways a society produces and consumes but also how it organizes itself to actually accommodate these fundamental ecological changes and meet the needs of the future generations. Degrowth does not only represent a reduction in economic activity but a broader transformation of society, values, and practices to accommodate these changes by depoliticizing the growth debate [36].

Degrowth questions the ways that we do "business as usual", including our measures of success and helps us to mindfully consider, "what do we aim to achieve, and why?" Then, to mindfully reflect on how we should best go about achieving these goals, degrowth scholar Giorgos Kallis notes:

"In economic terms, degrowth refers to a trajectory where the 'throughput' (energy, materials and waste flows) of an economy decreases while welfare, or well-being, improves. The hypothesis is that degrowing throughput will in all likelihood come with degrowing output, and that these can only be outcomes of a social transformation in an egalitarian direction. [...] But the definition is clear. [...] Degrowth is when social and environmental conditions improve, and GDP inevitably declines as a result". $(2018$, p.9)

While degrowth advocates toward putting "limits of growth", it does not mean antigrowth. Rather it is sometimes understood as "de-emphasizing" growth, or "de-centering" economic growth as the goal and measure of success. Degrowth promotes transformative change in society at large that is not only a shift in economic models but also has the potential to help shift us to embrace an ecosocial worldview that strengthens relationships to people and place and elevates the knowledge commons.

Degrowth involves localizing solutions and is not only about a shift in economic ideology. It focuses on cooperation, sharing the abundance, and reciprocity-based relationships among people and the planet [23]. This involves identifying alternative measures of "well-being" which would not be wedded to mere economic gain. The growth ideology promotes solutions which give preference to profit, and primarily benefit those with power. Instead, we can adopt non-economically centered indicators of prosperity that are within the ecosocial worldview. By moving beyond sustainable development to degrowth as transformational alternatives, we can open up pathways for a legitimately sustainable future with climate justice for all. Next, we offer some examples of solutions within the degrowth approach to help contextualize and make these abstract concepts much more concrete.

\section{Exemplars of Current Solutions: Degrowth for a Sustainable New Normal}

There are abundant examples from around the world which offer solutions within a degrowth approach. We want to emphasize that these approaches are not necessarily new or radical, rather, they are creative, local approaches of re-conceptualizing community and are also realistic and effective. We present some examples of current solutions within 
the degrowth discourse that employ an ecosocial worldview, leading us to envision and co-create a sustainable new normal.

Time-banking [37] has been a widely implemented tool which removes the monetary exchange of economics and utilizes hours of service in one's area of expertise to be "banked" then recouped in utilizing another's hour of service (for example, one may offer car maintenance for elder care) [38].

Indigenous approaches often align with degrowth as they hold perspectives that are contrary to the growth ideology. Shokane and Masoga [39] centralize Indigenous peoples' knowledges, values, and skills to solve climate justice problems. Using an Afrosensed theoretical framework, they note that social workers work with communities to enhance and promote the skills and knowledge about water shortages which have been embedded and passed down through generations, such as digging boreholes or rainmaking rituals. This knowledge is developed over generations of a relationship with the land and directed at the survival of the local community, especially during periods of crisis. This contrasts to solving a water shortage problem by bringing in non-local, not sustainable solutions that become quickly unmanageable and/or create cultural upheaval by shifting power dynamics.

Another concept that fits within the degrowth approach is the development of circular economies. A circular economy is designed to be regenerative, rather than exploitive. It aims to decouple our economy from the consumption of finite resources, moving us away from our linear model (such as growth ideology) of taking from the environment to make products which generates waste (as products and byproducts) that is then disposed of back in the environment [40]. One social worker envisioned a solution to the problem of disposal of solid waste on the island of Rarotonga utilizing principles of circular economies [41]. Waste was being disposed of in a landfill on the island that was reaching capacity. The mountainous terrain of the island left no other potential landfill sites. Alvero studied the work of a company in Brazil that presented a possible solution to the problem. This company recovers organic waste from restaurants, supermarkets, residential complexes, and catering companies. Through a special process, the waste is converted into compost that is then used as a fertilizer to grow food. This approach builds on the connections between people and environment rather than exploiting the environment.

Social connections are essential to well-being in degrowth approaches. Strengthening those relationships impacts well-being in a community, such as fostering social ties for solidarity and social capital. For example, the Greensboro Farmers Curb Market (GFCM), a local non-profit in North Carolina and a host agency for a social work intern, aims to create more equitable and sustainable, local food systems. The GFCM nurtures both sides of a healthy food system, creating sustainable economic livelihoods for farmers by directly connecting them to consumers. The GFCM has several food security programs which provide matching dollars for produce purchased at the GFCM by people who have SNAP/WIC and/or for individuals experiencing economic disparities (e.g., senior adults). These programs not only offer the obvious benefit of more food for their dollars, but the additional benefit of healthy, nutritious produce, not always readily available in food insecure communities, and the relationships that grow between vendors and other patrons at the market (i.e., social capital) (see https:/ / www.gsofarmersmarket.org/fresh-foodaccess /, accessed on 20 July 2021).

As a social work practitioner working in refugee resettlement, the first author helped re-envision and co-create a job sharing cooperative among two women with children. The refugee resettlement program dictated that their "success" was only counted when each woman was employed full-time. However, if each woman worked full time and had to pay for full time childcare, not only would they miss out on being home with her children, but they would endure the expense of childcare and barriers to transportation, which was nearly as great as her income. Instead, the team was able to arrange with an employer to hire both women to share one full-time, advertised position (in housekeeping), and on each of their days off from their paid work they would provide childcare, at no cost, 
for the other woman. This not only speaks to the flaws in measurement of "success" and "self-sufficiency" in the refugee resettlement programs, but also highlights the enormous oversight of unpaid labor of caregiving as unseen and the impacts as it further marginalizes women [7].

\section{Avenues for Future Scholarship}

We assert that the following aspects could be considered, and efforts could be made to manifest this sustainable new normal within the social work profession and beyond.

Individual worldview: Examining our individual worldview, beliefs, and attitudes towards the Web of Life is a necessary starting point for change as we further this journey of unlearning. We need to explore how being human-centric separates us from nature and how this separation perpetuates the oppression of people and planet [42]. This leads us to embracing an ecosocial worldview as the sustainable new normal so that all social work is seen as ecosocial work, not as some niche practice area.

Teaching: We need to challenge the knowledges that we are privileging in our teaching and passing on to the next generation of social workers as part of the professional socialization process. Recognizing that social work has infused many of the values of growth within our models, beliefs and practices necessitates decolonizing our profession [43]. We are not suggesting that we appropriate other models, colonizing in a different way; instead, we need to examine these alternative models to advance an ecosocial worldview and move us to a sustainable new normal. The path forward requires upending the mainstream curriculum, infusing the ecosocial perspective throughout.

Practice: We need to identify the practice models that transform our society to one that is ecologically just and sustainable versus those that plug the holes in the current model of growth and unsustainability. These innovations often occur at the local, small non-profit, NGO level, as one practitioner working from an ecosocial perspective can have a larger impact on changing organizational practices that are often entrenched in the "we've always done it this way" thinking [44].

Policy: A strength of the social work approach is that we understand the essential purpose policy serves in the lives of communities and individuals. Policies that forward an ecosocial worldview are needed. For example, we must advocate for changes in immigration policies such as expanding the definition of refugee status to include ecological hardships and climate injustices [45]. We also need professional bodies to issue policy statements on the urgency of climate justice, the need to reject growth ideology, and embrace ecosocial worldview for new ways of making change in the world.

Research: Research has an important role in examining current innovative practices, policies, and programs that fit within the degrowth approach that are already transforming communities. Implementation research is an appropriate method as it seeks to identify the factors, processes, and practices used in these innovations, allowing communities to co-create and adapt to their own local context [46,47]. Participatory models of research are consistent with the aim of co-creation essential in the ecosocial perspective [48].

Dissemination: Mainstream models of dissemination of knowledge are often exclusionary. Inclusive practices include collaborating with community co-authors in the research and dissemination process, publishing in quality, open access journals that are easily accessible to practitioners, researchers, and community members, and emphasis on interdisciplinary research to reduce silos of thinking and dissemination of knowledge in ways that acknowledge and value different ways of knowing. For example, interdisciplinary degrowth convenings offer spaces for community members, artists, academics, and others to share via multiple platforms such as a protest/march organized during a conference, a collective art installation done by conference participants, dance, movement, and/or oral storytelling. These practices emphasize that in order to co-create sustainable solutions, knowledge must be co-created by and equitably accessible by everyone. 


\section{Conclusions: Manifesting a Sustainable New Normal}

Social work's history and current professional mandates incite us to attend to ecological justice, as well as social sustainability, issues further exacerbated by the COVID-19 crisis. However, these moments of crises implore us to re-examine our worldviews that landed us in these predicaments. There is little room for the current mainstream thinking of relentless economic growth, which largely perpetuates competition for finite resources and incites individualism and greed. In recognizing the flaws of the growth ideology, social work as a profession can unwed itself from the systems and structures that perpetuate the injustices we work so tirelessly to alleviate for our communities and clients. It will require true participatory methods, centering and valuing local and Indigenous knowledges for solutions, and creating space for decolonizing. Above, we offered a few specific examples of solutions from social workers already embracing an ecosocial worldview and operating within the degrowth approach. These examples help us see that envisioning and co-creating a sustainable new normal is not "pie in the sky" thinking, but realistic for our urgent call to course correct. We now pose these questions to prompt further discussion among the profession and our community partners: how can we co-create sustainable new normal for our profession and how do we embed it as mainstream social work?

Social workers must advocate for an ecosocial worldview by engaging with the global partners around the world. By returning to our roots, even prior to becoming a profession, we can re-join those who have continued to embrace an ecosocial worldview (i.e., Indigenous and traditional perspectives). Social work must no longer operate within nor endorse structures and ideologies that create and perpetuate these problems for our world in the first place. We are not only continuing our honorable journey as a profession that responds to such injustices, but we must now co-lead a way forward to co-creating a sustainable new normal.

Author Contributions: Conceptualization: M.P. and M.R.; investigation, M.P., M.R. and P.K.; writing — original draft preparation: M.P., M.R. and P.K.; writing—review and editing: M.P., M.R. and P.K. All authors have read and agreed to the published version of the manuscript.

Funding: This research received no external funding.

Data Availability Statement: Not applicable.

Conflicts of Interest: The authors declare no conflict of interest.

\section{References}

1. Amadasun, S. Social work and COVID-19 pandemic: An action call. Int. Soc. Work. 2020, 63, 753-756. [CrossRef]

2. Shanondora, B.; Beltrán, R.; Brown, D.; Mitchell, F.M.; Fernandez, A. Indigenous Perspectives for Strengthening Social Responses to Global Environmental Changes: A Response to the Social Work Grand Challenge on Environmental Change. J. Community Pract. 2019, 27, 296-316.

3. Colomeda, L.A. Keepers of the Central Fire: Issues in Ecology for Indigenous Peoples; Jones and Bartlett: Boston, MA, USA, 1999.

4. Rinkel, M.; Powers, M. Social Work Promoting Community and Environmental Sustainability: A Workbook for Global Social Workers and Educators; International Federation of Social Workers: Rheinfelden, Switzerland, 2017.

5. Rambaree, K.; Powers, M.C.F.; Smith, R.J. Ecosocial work and social change in community practice. J. Community Pract. 2019, 27, 205-212. [CrossRef]

6. Taylor, S.R. We will not Go Back to Normal. Available online: https://www.instagram.com/p/B-fc3ejAlvd/ (accessed on 2 April 2020).

7. Powers, M.C.; Rambaree, K.; Peeters, J. Degrowth for transformational alternatives as radical social work practice. Crit. Radic. Soc. Work. 2019, 7, 417-433. [CrossRef]

8. Jones, D.N.; Powers, M.; Truell, R. Global agenda for social work and social development, third report: Promoting community and environmental sustainability. In Global Overview; International Federation of Social Workers (IFSW): Rheinfelden, Switzerland, 2018; pp. 1-50.

9. Raworth, K. Doughnut Economics: Seven Ways to Think like a 21st-Century Economist; Chelsea Green Publishing: Hartford, VT, USA, 2017.

10. Emas, R. The concept of sustainable development: Definition and defining principles. In Brief for GSDR; 2015. Available online: https: / / asset-pdf.scinapse.io/prod/2184349672/2184349672.pdf (accessed on 20 July 2021). 
11. Holden, E.; Linnerud, K.; Banister, D. Sustainable development: Our common future revisited. Glob. Environ. Chang. 2014, 26, 130-139. [CrossRef]

12. Borowy, I. Defining Sustainable Development for Our Common Future: A History of the World Commission on Environment and Development (Brundtland Commission); Routledge: London, UK, 2013.

13. Sneddon, C.; Howarth, R.B.; Norgaard, R.B. Sustainable development in a post-Brundtland world. Ecol. Econ. 2006, 57, 253-268. [CrossRef]

14. Barkemeyer, R.; Holt, D.; Preuss, L.; Tsang, S. What happened to the 'development' in sustainable development? Business guidelines two decades after Brundtland. Sustain. Dev. 2014, 22, 15-32. [CrossRef]

15. Peeters, J. Sustainable development: A mission for social work? A normative approach. J. Soc. Interv.: Theory Pract. 2012, 21, 5-22. [CrossRef]

16. Schouten, G.; Glasbergen, P. Creating legitimacy in global private governance: The case of the Roundtable on Sustainable Palm Oil. Ecol. Econ. 2011, 70, 1891-1899. [CrossRef]

17. Demaria, F.; Schneider, F.; Sekulova, F.; Martínez-Alier, J. What is degrowth? From an activist slogan to a social movement. Environ. Values 2013, 22, 191-215. [CrossRef]

18. Boron, S.; Murray, K. Bridging the unsustainability gap: A framework for sustainable development. Sustain. Dev. 2004, 12, 65-73. [CrossRef]

19. UN. Sustainable Development Goals. Available online: http://www.un.org/sustainabledevelopment/ (accessed on 22 February 2016).

20. Kopnina, H. The victims of unsustainability: A challenge to sustainable development goals. Int. J. Sustain. Dev. World Ecol. 2016, 23, 113-121. [CrossRef]

21. Heikkurinen, P. Degrowth by means of technology? A treatise for an ethos of releasement. J. Clean. Prod. 2018, 197, 1654-1665. [CrossRef]

22. Peeters, J. A safe and just space for humanity: The need for a new concept of well-being. In Ecological Social Work: Towards Sustainability; McKinnon, T.J., Alston, M., Eds.; Palgrave: London, UK, 2016; pp. 177-196.

23. Peeters, J. Promoting Sustainability by a Paradigm Shift towards Commons; International Federation of Social Workers: Rheinfelden, Switzerland, 2017.

24. Besthorn, F.H.; McMillen, D.P. The Oppression of Women and Nature: Ecofeminism as a Framework for an Expanded Ecological Social Work. Fam. Soc. 2002, 83, 221-232. [CrossRef]

25. IFSW. 2020 to 2030 Global Agenda for Social Work and Social Development Framework: 'Co-Building Inclusive Social Transformation'. Available online: https:/ / www.ifsw.org/2020-to-2030-global-agenda-for-social-work-and-social-developmentframework-co-building-inclusive-social-transformation/ (accessed on 19 July 2021).

26. Zapf, M.K. Transforming Social Work's Understanding of Person and Environment: Spirituality and the "Common Ground". J. Relig. Spiritual. Soc. Work.: Soc. Thought 2008, 27, 171-181. [CrossRef]

27. Van Dorn, A.; Cooney, R.E.; Sabin, M.L. COVID-19 exacerbating inequalities in the US. Lancet (Lond. UK) 2020, 395, 1243-1244. [CrossRef]

28. Rinkel, M.; Powers, M. Social Work Promoting Community and Environmental Sustainability: A Workbook for Global Social Workers and Educators; International Federation of Social Workers: Rheinfelden, Switzerland, 2019; Volume 3.

29. Gray, M.; Coates, J.; Hetherington, T. Introduction: Overview of the Last Ten Years and Typology of ESW; 2013. Available online: https:/ / www.taylorfrancis.com/chapters/edit/10.4324/9780203095300-6/introduction-overview-last-ten-years-typologyesw-mel-gray-john-coates-tiani-hetherington (accessed on 20 July 2021).

30. Dominelli, L. Green Social Work: From Environmental Crises to Environmental Justice; Polity; 2012. Available online: https://www. wiley.com/en-us/Green+Social+Work\%3A+From+Environmental+Crises+to+Environmental+Justice-p-9780745654003 (accessed on 20 July 2021).

31. Powers, M.C. Transforming the profession: Social workers' expanding response to the environmental crisis. In Ecosocial Transition of Societies: Contribution of Social Work and Social Policy; Routledge: New York, NY, USA, 2016.

32. Haila, Y. Beyond the nature-culture dualism. Biol. Philos. 2000, 15, 155-175. [CrossRef]

33. Matthies, A.L.; Peeters, J.; Hirvilammi, T.; Stamm, I. Ecosocial innovations enabling social work to promote new forms of sustainable economy. Int. J. Soc. Welf. 2020, 29, 378-389. [CrossRef]

34. D'Alisa, G.; Demaria, F.; Kalli, G. Degrowth: A Vocabulary for a New Era; Routledge: London, UK, 2014.

35. Kallis, G. Degrowth Newcastle; Agenda Publishing: Newcastle Upon Tyne, UK, 2018.

36. Robra, B.; Heikkurinen, P. Degrowth and the Sustainable Development Goals. In Decent Work and Economic Growth: Encyclopedia of the UN Sustainable Development Goals; Springer: Berlin/Heidelberg, Germany, 2019.

37. Ryan-Collins, J.; Stephens, L.; Coote, A. The New Wealth of Time: How Timebanking Helps People Build Better Public Services; New Economics Foundation: London, UK, 2008.

38. Cahn, E.; Gray, C. The Time Bank Solution. Stanf. Soc. Innov. Rev. 2015, 13, 40-45.

39. Shokane, A.L.; Masoga, M.A. African indigenous knowledge and social work practice: Towards an Afro-sensed perspective. South Afr. J. Soc. Work. Soc. Dev. 2018, 30, 18. [CrossRef]

40. Kirchherr, J.; Reike, D.; Hekkert, M. Conceptualizing the circular economy: An analysis of 114 definitions. Resour. Conserv. Recycl. 2017, 127, 221-232. [CrossRef] 
41. Alvero, L. Agitating through an alternate economy: Social work, sustainability, and the circular economy. In Social work Promoting Community E Environmental Sustainability: A Workbook for Global Social Workers E Educators; Powers, M.C.F., Rinkel, M., Eds.; IFSW: Rheinfelden, Switzerland, 2017; pp. 35-44.

42. Rinkel, M.; Mataira, P. Developing Critical Self-Awareness to Incorporate Sustainability into Worldviews. In Social Work Promoting Community and Environmental Sustainability: A Workbook for Social Work Practitioners and Educators, 2nd ed.; Powers, M.C.F., Rinkel, M., Eds.; IFSW: Rheinfelden, Switzerland, 2018; pp. 30-45.

43. Coates, J.; Hetherington, T. Decolonizing Social Work; Routledge: London, UK, 2016.

44. Bell, K. Transforming Social Work for Environmental Justice: Theory, Practice, and Education. Aust. Soc. Work. 2019, 72, 242-244. [CrossRef]

45. Powers, M.C.F.; Nsonwu, C.Z. Environmental Injustices Faced by Resettled Refugees. In Community Practice and Social Development in Social Work; Todd, S., Drolet, J.L., Eds.; Springer Singapore: Singapore, 2020; pp. 385-399.

46. Brownson, R.C.; Jacobs, J.A.; Tabak, R.G.; Hoehner, C.M.; Stamatakis, K.A. Designing for Dissemination Among Public Health Researchers: Findings From a National Survey in the United States. Am. J. Public Health 2013, 103, 1693-1699. [CrossRef] [PubMed]

47. Tabak, R.G.; Khoong, E.C.; Chambers, D.A.; Brownson, R.C. Bridging Research and Practice: Models for Dissemination and Implementation Research. Am. J. Prev. Med. 2012, 43, 337-350. [CrossRef] [PubMed]

48. Mason, L.R.; Shires, M.K.; Arwood, C.; Borst, A. Social work research and global environmental change. J. Soc. Soc. Work. Res. 2017, 8, 645-672. [CrossRef] 